\title{
Ensino Religioso, Pastoral e Catequese: proximidades, distâncias e desafios
}

SÉrgio G. Mendes ${ }^{1}$

Resumo: No contexto do crescente pluralismo da sociedade brasileira, o Ensino Religioso se apresenta para a escola católica como uma oportunidade especial de formação para a tolerância e a cidadania. Não obstante, nas escolas católicas ainda se presenciam modelos de Ensino Religioso que se confundem com a Catequese ou com a Pastoral Escolar. Além disso, faz-se necessário discernir, para cada contexto, o modelo de Ensino Religioso mais adequado: o catequético (ou confessional católico em sentido estrito), o inter-religioso (interconfessional, teológico ou ecumênico) ou o fenomenológico. De qualquer modo, a BNCC apresenta ainda novas exigências para a elaboração das matrizes do Ensino Religioso do Ensino Fundamental que são difíceis de serem acolhidas pelo modelo catequético. Contudo, a questão de fundo talvez não seja tanto a dificuldade sobre qual modelo de Ensino Religioso adotar ou sobre qual sua relação com a Pastoral Escolar em particular, mas a compreensão do que seja a evangelização e a pré-evangelização. Defende-se que o modelo fenomenológico não fere a confessionalidade da escola católica e que é o mais adequado para atender às exigências do contexto atual no campo do Ensino Religioso.

Palavras-chave: Religião. Educação. Escola católica. Ensino religioso.

\section{Religious, Pastoral and Catechetical Teaching: proximity, distances and challenges}

Abstract: In the context of the growing pluralism of our society, Religious Education presents it self to the Catholic school as a special opportunity of formation for tolerance and citizenship. Nonetheless, in Catholic schools we still see models of Religious Education that are confused with Catechesis or with School Ministry. In addition, it is necessary to discern, for each context, the most appropriate model of Religious Education: the Catechetical (or confessional Catholic in the strict sense), Interreligious (interconfessional, theological or ecumenical) or Phenomenological. In any case, the new brazilian curricular standards known as the Base Nacional Comum Curricular (BNCC) also presents new requirements for the elaboration of the matrices of Religious Education of Elementary School that are difficult to be accepted by the catechetical model. However, the fundamental question may not be so much the difficulty in which model of Religious Education to adopt or in what its relation with the School Ministry in particular, but the understanding of what is evangelization and pre-evangelization. 
We defend that the phenomenological model does not hurt the confessionality of the Catholic school and that it is the most adequate to meet the demands of the current context in the field of Religious Education.

Keywords: Religion. Education. Roman catholic school. Religious education.

\section{Enseñanza Religiosa, Pastoral y Catequesis: proximaciones, distancias y desafíos}

Resumen: En el contexto de creciente pluralismo de nuestra sociedad, la Educación Religiosa se presenta para la escuela católica como una oportunidad especial de formación para la tolerancia y la ciudadanía. No obstante, en las escuelas católicas todavía presenciamos modelos de Enseñanza Religiosa que se confunden con la Catequesis o con la Pastoral Escolar. Además, se hace necesario discernir, para cada contexto, el modelo de Enseñanza Religiosa más adecuado: el Catequético (o confesional católico en sentido estricto), el Interreligioso (interconfesional, teológico o ecuménico) o el Fenomenológico. De cualquier modo, los lineamientos curriculares brasileños, la llamada "Base Nacional Comum Curricular" (BNCC), presenta nuevas exigencias para la elaboración de los lineamientos curriculares de la Educación Religiosa de Primaria y Secundaria, que son difíciles de ser acogidas por el modelo catequético. Sin embargo, la cuestión de fondo tal vez no sea tanto la dificultad sobre qué modelo de Educación Religiosa adoptar o sobre cuál su relación con la Pastoral Escolar en particular, sino la comprensión de lo que es la evangelización y la pre-evangelización. Defendemos que el modelo fenomenológico no hiere la confesionalidad de la escuela católica y que es el más adecuado para atender a las exigencias del contexto actual en el campo de la Enseñanza Religiosa. Palabras clave: Religión. Educación. Escuela católica. Enseñanza religiosa.

\section{Introdução}

Desde o processo de formação do Estado brasileiro, o tema do Ensino Religioso acompanha a história do país. Hoje, no momento em que se assiste ao recrudescimento da intolerância e do fundamentalismo como reação a uma sociedade cada vez mais plural, o Ensino Religioso se apresenta novamente como um tema de máxima importância. Com efeito, passa também por esse componente curricular a preocupação com a formação para a tolerância, a cidadania e o respeito às diversidades. No presente estudo, não se objetivou recordar ou sistematizar tudo o que o magistério recente afirmou sobre essa temática, mas, a partir de alguns de seus pressupostos e dos novos desafios que interpelam, propor algumas reflexões que possam contribuir para o juízo sobre os modelos de Ensino Religioso que atualmente são adotados em algumas escolas católicas do Brasil.

Muitos documentos do magistério católico trataram do Ensino Religioso. Sem a pretensão de um elenco exaustivo, convém citar os seguintes:

- Exortação Apostólica Catechesi Tradendae (1979).

- Dimensão religiosa da educação na escola católica (1988). 
- Educar hoje e amanhã: uma paixão que se renova (2014).

- O apostolado do Ensino Religioso nas escolas católicas (1996).

- A escola católica (1977).

- Diretório Geral para a Catequese (1998).

- Igreja e educação (1975).

- Educação religiosa nas escolas (1976).

- Educação, Igreja e sociedade (1992).

- O Ensino Religioso - nas constituições do Brasil, nas legislações de ensino (1987).

Como demonstram esses e outros documentos eclesiais, a compreensão sobre o Ensino Religioso ao longo da tradição católica conheceu algumas mudanças profundas. De fato, desde os fins da Idade Média até os anos próximos ao Concílio Vaticano II, há, no âmbito da escola católica, praticamente uma coincidência entre Ensino Religioso Escolar, Pastoral e Catequese. Mas, após o Concílio Vaticano II, há uma crescente clareza acerca da especificidade de cada uma dessas realidades. Em especial, a distinção entre Catequese e Ensino Religioso se aprofundou por força da compreensão de que a Catequese não poderia se restringir ao domínio cognitivo das verdades fundamentais da fé católica como acontecia naquela ocasião. Enfim, Catequese, Ensino Religioso e Pastoral não são mais compreendidas como ações coincidentes, mas são complementares na missão evangelizadora da escola católica.

\section{A Pastoral e a Catequese na escola católica}

Antes de se ater ao Ensino Religioso, fio condutor desta reflexão, convém considerar as especificidades da Pastoral e da Catequese. Desse modo, será mais fácil perceber o campo próprio do Ensino Religioso nas escolas católicas.

\section{A pastoral}

A Pastoral, em sentido amplo, é o agir da Igreja (todo o Povo de Deus), prolongando, na história, a presença e a atuação do Senhor Jesus como revelador do Pai e libertador dos seres humanos (CONFERÊNCIA NACIONAL DOS BISPOS DO BRASIL, 1986, p. 22). À Pastoral cabe de maneira singular a missão de criar na escola católica um "ambiente permeado do espírito evangélico de caridade e liberdade", em que se perceba a presença da docência humanizadora de Jesus, um estilo cristão de pensamento e de vida que penetra em cada um dos elementos da estrutura educativa (CONGREGAÇÃO PARA A EDUCAÇÃO CATÓLICA, 1988, n. 25). Em décadas recentes, cresceu a percepção entre as instituições educativas católicas da necessidade de se passar de uma escola com 
Pastoral para uma escola em Pastoral. Isso implica que a Pastoral deixe de ser um setor da escola e integre a gestão escolar, o currículo, a ação pedagógica, a administração e a formação dos educadores e funcionários.

\section{A Catequese}

A Catequese pressupõe a aceitação vital da mensagem cristã como realidade salvífica, o que não se aplica ao Ensino Religioso. E o lugar específico da Catequese é uma comunidade que vive a fé em um espaço mais vasto e por um período mais longo do que o escolar. A Catequese objetiva a maturação espiritual, litúrgica, sacramental, apostólica, que se realiza sobretudo na comunidade eclesial local (CONGREGAÇÃO PARA A EDUCAÇÃO CATÓLICA, 1988, n. 68-70). Por essa razão, ainda que seja desejável que a escola católica também ofereça essa possibilidade de maturação da fé cristã para os discentes que o desejarem, é imprescindível que o faça em vínculo com a igreja local.

Cabe, no entanto, considerar que algumas escolas católicas chegaram a fundir de tal modo o Ensino Religioso à Catequese, que elas se tornaram um único caminho de preparação aos sacramentos. Essa identificação ignora a necessária distinção e complementaridade que deve perpassar essas duas realidades (CONGREGAÇÃO PARA O CLERO, 1997, n. 73). Essa fusão compromete em especial o propósito fundamental da Catequese, na medida em que volta a reduzi-la à transmissão de verdades, ignorando que ela visa ser uma pedagogia integral da fé, a partir de um encontro profundo com o Cristo Ressuscitado, da identificação com a sua missão de promoção do Reino de Deus no mundo e da participação em uma comunidade concreta de seus seguidores (CONGREGAÇÃO PARA O CLERO, 1997, n. 30-33, 39, 68, 80; JOÃO PAULO II, 1984, n. 20; ALBERICH, 1983).

\section{O Ensino Religioso na escola católica}

O Ensino Religioso não supõe a adesão à fé religiosa. Trata-se de um componente curricular com um programa próprio que busca relações inter e transdisciplinares (CONGREGAÇÃO PARA A EDUCAÇÃO CATÓLICA, 1988, n. 70). Por essa razão, o Ensino Religioso possui objetivos, planos, didática e características próprias, conforme diretrizes pedagógicas da escola.

Não obstante, o Ensino Religioso quer ser uma oportunidade de diálogo entre a tradição da fé cristã e a cultura, de tal sorte que os valores do Evangelho possam impregnar a mente e os corações dos alunos (CONGREGAÇÃ̃ PARA O CLERO, 1997, n. 73-75).

Dada a confessionalidade da escola católica e as bases legais que a sustentam, é necessário recordar que o Ensino Religioso por ela oferecido pode restringir-se exclusivamente à exposição da doutrina católica e sua visão religiosa 
particular. Os pais, ao matricularem seus filhos em uma escola católica, concordaram tacitamente com a orientação católica não apenas do Ensino Religioso, mas de toda a estrutura escolar. Logo, do ponto de vista legal, nada obsta a que a escola católica faça livremente essa escolha.

\section{Os novos desafios do Ensino Religioso na escola católica}

Ao tratar do Ensino Religioso na escola pública, o Papa São João Paulo II defendia que os alunos têm o direito de aprender, de modo verdadeiro e com certeza, a religião a que pertencem (JOÃO PAULO II, 1991)². Esse direito é reconhecido teoricamente pela legislação brasileira, ainda que efetivamente as religiões minoritárias não tenham estrutura nem recursos para oferecer esse direito aos seus estudantes da escola pública. Por outro lado, a Base Nacional Comum Curricular (BNCC) reconhece esse direito ao aluno, mas em chave inter-religiosa e filosófica. $\mathrm{Na}$ introdução à área do Ensino Religioso, a BNCC reconhece que ele é parte incontornável da cultura:

O conhecimento religioso, objeto da área de Ensino Religioso, é produzido no âmbito das diferentes áreas do conhecimento científico das Ciências Humanas e Sociais, notadamente da(s) Ciência(s) da(s) Religião(ões). Essas Ciências investigam a manifestação dos fenômenos religiosos em diferentes culturas e sociedades enquanto um dos bens simbólicos resultantes da busca humana por respostas aos enigmas do mundo, da vida e da morte. De modo singular, complexo e diverso, esses fenômenos alicerçam distintos sentidos e significados de vida e diversas ideias de divindade(s), em torno dos quais se organizam cosmovisões, linguagens, saberes, crenças, mitologias, narrativas, textos, símbolos, ritos, doutrinas, tradições, movimentos, práticas e princípios éticos e morais. Os fenômenos religiosos em suas múltiplas manifestações são parte integrante do substrato cultural da humanidade (BRASIL, 2017, p. 436, grifos nossos).

Reconhece ainda que o Ensino Religioso é necessário na formação para a tolerância e a cultura de paz:

O Ensino Religioso busca construir, por meio do estudo dos conhecimentos religiosos e das filosofias de vida, atitudes de reconhecimento e respeito às alteridades. Trata-se de um espaço de aprendizagens, experiências pedagógicas, intercâmbios e diálogos permanentes, que visam o acolhimento das identidades culturais, religiosas ou não, na perspectiva da interculturalidade, direitos humanos e cultura da paz. Tais finalidades se articulam aos elementos da formação integral dos estudantes, na medida em que fomentam a aprendizagem da convivência democrática e cidadã, princípio básico à vida em sociedade (BRASIL, 2017, p. 437). 
E, por fim, reconhece a importância da dimensão transcendental humana:

A dimensão da transcendência é matriz dos fenômenos e das experiências religiosas, uma vez que, em face da finitude, os sujeitos e as coletividades sentiram-se desafiados a atribuir sentidos e significados à vida e à morte. $\mathrm{Na}$ busca de respostas, o ser humano conferiu valor de sacralidade a objetos, coisas, pessoas, forças da natureza ou seres sobrenaturais, transcendendo a realidade concreta (BRASIL, 2017, p. 438).

Mesmo que a escola católica insista em um Ensino Religioso confessional católico em sentido estrito, ainda assim a BNCC a obriga a abrigar em suas matrizes curriculares as competências, as habilidades e os objetos de conhecimento relativos a outras tradições religiosas ${ }^{3}$. Significa que a escola católica também deve objetivar a formação para o diálogo com a cultura, a tolerância religiosa, a cidadania e a cultura de paz. Na verdade, esses objetivos já têm sido almejados pela escola católica há muito tempo. A novidade é que, ao obrigar que o Ensino Religioso trate de outras tradições religiosas, a BNCC, na prática, dificulta um ensino confessional em sentido estrito, que exclua outras tradições religiosas como acontecia até recentemente em algumas escolas católicas. Além disso, a BNCC também aponta que o objeto desse componente curricular, como visto, é o "conhecimento religioso", porque se compreende o Ensino Religioso como uma verdadeira área de conhecimento. Novamente, um Ensino Religioso estritamente confessional e que se confunda com a Catequese, provavelmente, tenha muita dificuldade de atender a essas demandas da BNCC.

No entanto, quando a massiva maioria dos estudantes matriculados na escola católica era católica, a oferta de um Ensino Religioso estritamente católico não oferecia grandes dificuldades. Mas, atualmente, é crescente o número de alunos que se matriculam na escola católica pertencendo a outras tradições religiosas ou declarando-se agnósticos, ateus ou sem religião. Por ser confessional, isso não obriga a escola católica a modificar suas opções explicitamente católicas no campo do Ensino Religioso ou de qualquer outra parte de sua organização escolar.

Contudo, sendo a dimensão de abertura transcendental parte inequívoca de uma visão integral do ser humano, pode-se reconhecer que o desenvolvimento dessa dimensão é verdadeiramente um direito humano. Em um contexto de crescente pluralidade que afeta não apenas os alunos, mas o próprio corpo docente e os funcionários da escola católica, insistir e apenas tratar de maneira exclusiva a tradição católica, excluindo o diálogo com outras tradições religiosas e não religiosas, é correr o risco de não contribuir efetivamente para o desenvolvimento da dimensão transcendental humana, o que em chave católica significaria não contribuir para uma pré-evangelização, como bem expressa a Congregação para a Educação Católica (1988, n. 108, grifos nossos): 
Dada a situação que se criou em várias partes do mundo - a escola católica acolhe cada vez mais uma população escolar de fé e ideologias diversas - torna-se inadiável a necessidade de esclarecer a dialética a instaurar entre o momento cultural propriamente dito e o desenvolvimento da dimensão religiosa. Esta é um momento ineliminável, e permanece a tarefa específica de todos os cristãos empenhados nas instituições educativas. Em tais situações, porém, não será sempre fácil ou possível conduzir avante o discurso da evangelização; dever-se-á então ter em vista a pré-evangelização, isto é, a abertura ao sentido religioso da vida. Isto comporta uma individualização e aprofundamento de elementos positivos acerca do como e do conteúdo do processo formativo específico. A transmissão da cultura deve estar atenta antes de mais à consecução dos próprios fins e a potenciar todas as dimensões que tornam o homem humano, e em particular a dimensão religiosa e o emergir da exigência ética. Tendo em conta a unidade no pluralismo, é necessário realizar um discernimento sagaz entre o que é essencial e o que é acidental. A exatidão do como e do conteúdo consentirá o desenvolvimento integral do homem no processo educativo, desenvolvimento que pode ser definido verdadeira pré-evangelização. Este é o terreno sobre o qual se pode "edificar".

Logo, apresenta-se uma nova exigência para o Ensino Religioso: o de contribuir para a formação integral dos alunos por meio do desenvolvimento da dimensão religiosa e do empenho ético. Diante desse cenário, cabe perguntar sobre qual modelo de Ensino Religioso na escola católica seria o mais adequado, sem ignorar, contudo, a atualíssima advertência da Congregação para o Clero (1997, n. 74):

Não é possível reduzir a uma única forma todos os modelos de ensinamento religioso escolar, desenvolvidos historicamente em seguida aos acordos com os Estados e às deliberações de cada Conferência dos Bispos. Todavia, é necessário esforçar-se para que, segundo os relativos pressupostos, o ensino religioso responda às suas finalidades e características peculiares.

\section{Modelos de Ensino Religioso}

A legislação brasileira, especialmente a partir da Constituição de 1934, foi progressivamente compreendendo o Ensino Religioso como um componente curricular ou uma área de conhecimento. Essa mudança na compreensão do papel e lugar do Ensino Religioso fomentou o surgimento de outros modelos de Ensino Religioso que aos poucos foram também acolhidos por algumas escolas católicas ${ }^{4}$. 


\section{Catequético (ou confessional católico em sentido estrito)}

É o modelo mais antigo do Brasil, uma vez que se apoiou durante longo tempo na hegemonia católica da sociedade. Seu traço característico é a exposição quase exclusiva da religião cristã, a partir da perspectiva católica. Tende, em muitos aspectos, a identificar-se com a Catequese. As escolas católicas que adotam esse modelo zelam para que o caráter confessional da escola se faça explícito de modo especial por meio do Ensino Religioso. Deseja-se nesse contexto que os alunos, independentemente de suas convicções religiosas, conheçam a fé cristã católica, entendam seus símbolos, reflitam sobre os diversos temas propostos pelo magistério católico. $\mathrm{O}$ aluno tende a ser visto aqui como um fiel ou alguém com potencial de vir a sê-lo.

Uma grande vantagem desse modelo é a de poder efetivamente contribuir para a superação de visões distorcidas a respeito do cristianismo católico, além de favorecer um desenvolvimento cognitivo mais amplo da doutrina cristã por parte dos estudantes católicos.

Nesse modelo de Ensino Religioso, está implícita a ideia de que os pais, ao matricularem seus filhos em uma escola católica, desejam uma formação na fé e doutrina católicas. Mas, na atualidade, esse pressuposto parece ser cada vez mais questionável.

Entre os limites que podem surgir nessa abordagem do Ensino Religioso, destacam-se:

- A tendência à doutrinação apologética e proselitista.

- Não contribuir efetivamente para a valorização da pluralidade religiosa dos próprios estudantes.

- Aumentar, naqueles alunos de outras opções religiosas e não religiosas, a aversão à tradição católica, por conta do caráter obrigatório desse componente curricular.

- A tendência a criar certa confusão nos alunos católicos acerca da diferença entre Ensino Religioso e Catequese, com possível prejuízo para esta.

Inter-religioso (interconfessional, teológico ou ecumênico)

Trata-se de uma aproximação mais acadêmica e transdisciplinar às tradições religiosas. Tende a identificar-se com uma antropologia das religiões ou um estudo comparado das religiões. Quando assume o caráter mais estritamente ecumênico, seleciona aqueles conteúdos que são comuns às diferentes denominações cristãs.

Nessa abordagem, objetiva-se a educação da religiosidade. Trata-se de compreender a busca humana pelo sentido da existência, da vida, do sofrimento 
e da morte, como expressão da abertura humana ao transcendente. É essa busca que foi paulatinamente condensada pelas tradições religiosas por meio de doutrinas, ritos e valores éticos. Logo, nesse modelo de Ensino Religioso, a religiosidade é compreendida como uma das dimensões antropológicas irrenunciáveis para uma educação que se pretenda verdadeiramente integral.

Esse modelo inter-religioso pode se configurar como uma propedêutica à fé religiosa, uma vez que "provoca" o aluno ao confronto com as mesmas questões e respostas que possibilitaram o surgimento das tradições religiosas.

Um pressuposto bastante coerente nessa abordagem do Ensino Religioso é de que há "sementes do verbo" em outras tradições religiosas, como reconhece a própria Igreja desde o Concílio Vaticano II (CONCÍLIO ECUMÊNICO VATICANO II, 1965, n. 11; CONCÍLIO ECUMÊNICO VATICANO II, 1964, n. 17). Por essa razão, a aproximação a outras tradições religiosas pode efetivamente tornar-se um caminho de introdução ao mistério de Deus. Se levar em conta que uma parte considerável dos alunos não foi iniciada a qualquer fé religiosa, incluindo muitos do que dizem professar alguma religião, mas são frequentadores eventuais, torna-se evidente que esse modelo de Ensino Religioso pode ser uma verdadeira iniciação.

Uma variante desse modelo inter-religioso é o Ensino Religioso de corte axiológico. Nesse caso, o diálogo com as diversas tradições religiosas ou filosóficas se faz a partir do eixo dos valores éticos. Desse modo, o Ensino Religioso se aproxima bastante de uma ética filosófica das religiões.

Contudo, entre os limites que podem surgir nessa abordagem, encontram-se:

- A tendência a considerar todas as expressões religiosas em pé de igualdade, o que pode conduzir a certo relativismo e subjetivismo religioso.

- Por considerar as religiões de forma homogênea, pode dificultar a crítica de determinadas práticas religiosas, uma vez que tais críticas poderiam ser interpretadas como falta de respeito à diversidade.

- Entender a abertura transcendental ou a dimensão religiosa de forma muito abstrata, impedindo uma compreensão adequada do sentido dado pelas diversas expressões religiosas para termos como "experiência religiosa", "fé", "mistério" etc.

- Transformar o Ensino Religioso em uma espécie de antropologia das religiões, atendendo mais à curiosidade dos alunos do que a um processo intencional de abertura ao mistério transcendente.

- Apesar de conceber que a religiosidade é uma dimensão antropológica anterior ao surgimento das religiões, esse modelo pode não dar conta de dialogar satisfatoriamente com aqueles alunos sem religião, agnósticos ou ateus. 


\section{Fenomenológico}

Trata-se da compreensão do Ensino Religioso como uma área de conhecimento segundo a perspectiva da fenomenologia da religião. O ponto de partida é o reconhecimento do ser humano como homo religiosus, que, a partir de perguntas fundamentais, encontra respostas e constrói as tradições religiosas ou filosóficas. Nessa perspectiva, a religiosidade deixa de ser compreendida de modo abstrato porque parte do fenômeno religioso tal como ele se manifesta na história.

Um traço característico da abordagem fenomenológica é que ela não parte de conceitos preestabelecidos para análise do fenômeno religioso, mas busca analisar os sentidos que o ser humano deu a sua própria existência pessoal e social, tanto nas tradições religiosas quanto nas não religiosas. É nessa busca pelo sentido que o ser humano encontra razões para sua autorrealização pessoal e coletiva. Isso não implica fazer um juízo sobre as doutrinas ou experiências religiosas, mas analisar como as pessoas que professam tais doutrinas ou realizam tais experiências as interpretam. Logo, as religiões são entendidas como fatos, não como objetos das ciências, por exemplo, a antropologia, a sociologia ou a filosofia, mas como fatos religiosos, cuja compreensão supõe o colocar-se na perspectiva religiosa para sua correta intepretação.

Por essas singularidades, o modelo fenomenológico é o mais acolhido nas escolas da rede pública. No entanto, justamente porque a diversidade encontrada na escola pública iguala-se cada vez mais a da escola confessional, esse modelo de Ensino Religioso também tem sido acolhido como alternativa viável nas escolas católicas. Além disso, esse modelo é o que melhor acolhe a diretriz da BNCC para o Ensino Religioso, conforme se apresentou anteriormente.

Um traço importante dessa abordagem fenomenológica é contribuir para a crítica sobre a tendência de subjetivação da escolha religiosa. De fato, à luz da fenomenologia, a religião deixa de ser compreendida como mera questão de foro íntimo, mas expressão de uma necessidade, de um desejo humano de sentido, que é objetivo e universal.

Não obstante, há que se reconhecer que, do ponto de vista das competências e habilidades requeridas para o professor de Ensino Religioso, essa abordagem é a mais exigente, pois supõe, além do estudo interdisciplinar do fenômeno religioso, a compreensão e o domínio didático do método fenomenológico.

Entre os limites que podem surgir nessa abordagem, um que se destaca é que, à semelhança do modelo inter-religioso, a abordagem fenomenológica pode conduzir a certo relativismo religioso, não porque todas as religiões seriam consideradas em pé de igualdade (como pode acontecer no modelo inter-religioso), mas porque o aluno poderá descobrir que efetivamente há profundas semelhanças entre as várias tentativas religiosas e não religiosas de dar sentido à existência humana. 
Ainda que boa parte dos documentos magisteriais se incline mais para a adoção do modelo catequético, há de se considerar que, dada a diversidade de contextos das escolas católicas brasileiras, pode ser razoável a adoção desse modelo naquelas escolas em que ainda há uma predominância massiva de alunos e famílias católicas. No entanto, essa realidade é mais frequente em áreas mais afastadas dos grandes centros urbanos.

No que se refere ao modelo inter-religioso, ele parece ter sido uma iniciativa de transição para o modelo fenomenológico. De fato, ao acompanhar os casos de aplicação desse modelo e os materiais didáticos correspondentes, pode-se perceber três tendências: ou acabou por se converter em uma ética religiosa (modelo axiológico), ou se converteu em uma ética filosófica, ou se converteu no modelo fenomenológico.

O modelo fenomenológico parece ser, atualmente, o mais adotado nas grandes redes católicas de educação, apesar de variantes na composição das matrizes curriculares do Ensino Religioso.

Em suma, mais do que a defesa irrestrita de alguns desses três modelos, é importante notar que o imperativo da missão educativa de evangelizar, para sua efetividade, supõe sempre a análise da realidade, a fim de utilizar os melhores meios disponíveis para que a Boa-Nova do Reino de Deus atinja o coração humano. Em um contexto social cada vez mais plural, as religiões têm o papel incontornável de colaborar para a construção de uma sociedade mais ética, justa e solidária. Esse é o apelo que os bispos dirigiram em Aparecida:

Constitui responsabilidade estrita da escola, enquanto instituição educativa, destacar a dimensão ética e religiosa da cultura, precisamente com o objetivo de ativar o dinamismo espiritual do sujeito e ajudá-lo a alcançar a liberdade ética que pressupõe e aperfeiçoa a psicológica (CELAM, 2007, n. 481).

\section{A confessionalidade católica do Ensino Religioso}

No contexto católico, uma crítica frequente aos modelos inter-religioso e fenomenológico é de que se está renunciando à confessionalidade católica das escolas e aceitando o relativismo da verdade ao igualar acriticamente todas as tradições religiosas, o que conduziria ao subjetivismo religioso. Parece que qualquer opção religiosa ou não religiosa possuiria o mesmo valor, tratar-se-ia apenas de uma escolha pessoal, que nunca deve ser criticada.

Nessa crítica, percebem-se basicamente duas forças argumentativas: a identidade da escola católica e a questão do relativismo ético-religioso. Proceder-se-á a uma análise mais profunda de ambas. 
Primeiramente, a questão da identidade católica não apenas se refere à escola, mas a toda a Igreja. O adjetivo católico aponta para a universalidade da Igreja. Desde o início, as primeiras comunidades cristãs entenderam que o mandato de Jesus de anunciar a Boa-Nova do Evangelho a todos os povos apresentava uma missão universal de propagação do Reino de Deus na Terra. Mas, historicamente, essa universalidade da Igreja foi com frequência compreendida como constituição de uma "cristandade universal", daí a preocupação das primeiras missões ultramarinas europeias em batizar os "convertidos" das novas terras colonizadas. Ora, é partir do resgate da história da salvação, acentuado pelo Concílio Vaticano II, como eixo iluminador da identidade católica, que a própria Igreja começou a compreender-se em chave trinitária, como Povo de Deus, Corpo de Cristo e Templo do Espírito Santo.

É então a partir da Trindade que se compreende a que tipo de universalidade a catolicidade da Igreja se refere: à unidade na diversidade. Em Deus a unidade entre Pai, Filho e Espírito Santo é sem "confusão", mantendo a diversidade das pessoas divinas (o Pai não é o Filho, que não é o Espírito Santo, que não é o Pai).

A Igreja como mistério de Deus é conduzida pelo Espírito Santo à configuração com Cristo no mundo. Significa que ela é, em mistério, a manifestação histórica da Trindade divina enquanto unidade na diversidade. O que fere a imagem trinitária da Igreja é a confusão entre unidade e uniformidade. Um traço característico da presença trinitária na história da Igreja Católica tem sido sua capacidade de agregar em seu seio uma diversidade enorme de expressões da fé, tradições litúrgicas, carismas, correntes de espiritualidade, movimentos eclesiais, institutos de vida consagrada etc.

Ora, a pluralidade que caracteriza a pós-modernidade, ainda que ofereça verdadeiramente o risco de um relativismo que abrace acriticamente como boas todas as manifestações religiosas ou não religiosas, oferece também à tradição católica uma oportunidade única de mostrar ao mundo sua vocação trinitária de unir os que estão dispersos, despertando em todos a percepção de uma fraternidade-sororidade universal, que, à luz da fé, brota da comum filiação de toda a humanidade em Cristo.

No caso concreto da escola católica, a opção em contribuir intencionalmente para a acolhida da diversidade como uma riqueza e como um dom, longe de distanciá-la de sua identidade católica, pode justamente ser a expressão mais genuína de sua missão universal de gerar a unidade na diversidade, convencida de que, efetivamente em Cristo, todos são um só: não havendo mais "nem judeu nem grego, escravo ou livre, homem ou mulher" (Gl 3,28). 
Quanto ao segundo problema, o do relativismo ético-religioso, a melhor forma de enfrentá-lo não é nem a apologia narcísica do "nada há de verdadeiro que não seja meu reflexo" e tampouco a ofensiva fundamentalista de "os inimigos devem ser eliminados". O melhor caminho para afrontar o relativismo é o diálogo sereno e racional. Ora, a possibilidade do diálogo na pós-modernidade supõe, entre outras coisas, a empatia, a capacidade de deixar-se afetar pelo outro, de apresentar-se desarmado. Só então a crítica pode apresentar-se como uma forma de mútua ajuda no caminho do crescimento.

Um dos grandes riscos da insistência na apresentação da verdade católica no âmbito do Ensino Religioso (modelo catequético) é o de produzir o efeito contrário ao desejado: estimular as hostilidades, acentuar o que separa, "convocar" em vez de "provocar" a adesão ao núcleo da fé cristã, a experiência de um amor incondicional, reduzindo a própria fé cristã a um conjunto de verdades.

\section{Os pressupostos teológicos dos modelos de Ensino Religioso}

Outra questão que deve ser considerada ao se realizar um juízo acerca dos modelos de Ensino Religioso é avaliar os pressupostos teológicos que os sustentam. De fato, no modelo confessional, algumas vezes pode estar pressuposto que os alunos ignoram a verdade da fé católica e que, por essa razão, ou vivem uma adesão débil ao cristianismo católico ou não são católicos. Logo, tratar-se-ia de afrontar tal ignorância por meio da apresentação da verdade da fé católica. O problema teológico de fundo é ignorar que a tradição da fé católica reconhece que há sementes do verbo espalhadas pelo mundo, compreendendo outras tradições religiosas e não religiosas (CONCİLIO ECUMÊNICO VATICANO II, 1965, n. 11; CONCÍLIO ECUMÊNICO VATICANO II, 1964, n. 17). Significa fazer coincidir o acesso ao mistério de Deus à adesão à fé cristã católica. Ora, isso trai a própria tradição da fé, na medida em que deixa de reconhecer a precedência do mistério de Deus, que se manifesta alhures antes mesmo do conhecimento da fé cristã católica. Nesse aspecto, os modelos inter-religioso e fenomenológico oferecem melhores chances do reconhecimento e da acolhida desse mistério de Deus.

\section{A necessária integração entre Ensino Religioso e Pastoral Escolar}

Um dos grandes desafios para a escola católica atualmente é acerca da clareza institucional sobre o papel e a missão da Pastoral Escolar. De fato, em muitas escolas católicas ainda predomina uma compreensão da Pastoral como um setor específico da escola responsável pelos diversos atos litúrgicos que se realizam no espaço escolar (celebrações, momentos de espiritualidade, práticas sacramentais etc.). 
Quando a Pastoral é entendida apenas como um setor da escola, haverá grande dificuldade de se criar um ambiente escolar que transpire os valores do Evangelho. Nesse caso, o Ensino Religioso, para muitos alunos, talvez seja a única oportunidade de contato com a tradição da fé católica.

Mas quando a escola se entende como uma escola em Pastoral, os valores do Evangelho se farão notar desde a acolhida na portaria da escola, passando pelo ethos cristão que perpassa as relações humanas que ocorrem no espaço escolar, alcançando as matrizes curriculares e todas as demais ações pedagógicas, visibilizando-se em um espaço marcado pelo cuidado com os mais pequenos detalhes. Significa ainda que a gestão escolar, por meio de seu plano de ação, estabelecerá resultados, metas, ações e indicadores para que esse ambiente seja cada vez mais inspirador e revelador da identidade cristã católica.

Sem uma escola em Pastoral, o Ensino Religioso realmente tenderá a ser a única expressão da fé católica na escola. Os demais símbolos religiosos da fé católica correrão o risco de ser sinais sem expressividade ou significado para aqueles que utilizam o espaço escolar.

É importante notar que a Pastoral Escolar é o espaço privilegiado para o amadurecimento na fé cristã pela possibilidade de criação de espaços e momentos especialmente dedicados à oração, à partilha, à ação social, à união de mentes e corações, em um grau e em uma intensidade que não é possível alcançar por meio das aulas de Ensino Religioso.

No contexto em que se vive atualmente nos grandes centros urbanos do Brasil, uma urgência crescente é despertar as crianças e os jovens para o reconhecimento da importância da dimensão religiosa no desenvolvimento integral da pessoa. Esse pressuposto, apesar da contradição de um mundo ainda muito marcado pela pluralidade religiosa, não é tão óbvio como se poderia esperar. De fato, muitos estudantes tendem a encarar a religião como uma realidade bastante secundária no horizonte pessoal de prioridades existenciais. Dessa forma, o Ensino Religioso pode se apresentar como uma oportunidade de despertar o desejo de cuidar da dimensão transcendental da própria existência por parte de cada estudante.

\section{O problema da formação e da qualificação de professores de Ensino Religioso}

Por fim, uma necessidade urgente no contexto do Ensino Religioso nas escolas confessionais católicas é a formação e a qualificação de professores. Embora nos últimos anos tenham se multiplicado os centros de formação para esse componente curricular (cursos de Ciências da Religião, cursos de Teologia, licenciaturas em Ensino Religioso, pós-graduações em Ciências das Religião, centros de Teologia para leigos etc.), as escolas católicas têm muita dificuldade para achar profissionais à altura da missão. Com relativa frequência, 
encontram-se pessoas com formação, mas sem as qualidades humanas necessárias para alcançar exitosamente os objetivos desse componente curricular; em outras ocasiões, o inverso: pessoas com todas as qualidades humanas, mas com formação insuficiente.

Entende-se que as qualidades humanas do professor de Ensino Religioso não são acessórias para esse componente curricular, na medida em que o seu êxito pedagógico passa necessariamente pelo seu testemunho pessoal de vida. Não significa que ele deva professar necessariamente a fé católica, mas que deve ao menos ser uma pessoa que manifesta o cultivo de sua dimensão espiritual. Sem isso, os alunos não tardarão a perceber a incoerência de suas palavras com suas atitudes e escolhas, o que fragilizará sua ação pedagógica nesse campo.

\section{Considerações finais}

A escola católica continua em sua ação educativa a participar da missão evangelizadora da Igreja. Mas as exigências do mundo atual apresentam alunos que são cada vez menos iniciados no horizonte religioso. Apesar de uma parcela significativa dos alunos confessar algum credo religioso, a realidade é que os laços de filiação religiosa são cada vez mais tênues. A religiosidade na pós-modernidade tem se tornado um vínculo opcional, provisório, ou, para utilizar uma expressão de Zygmunt Bauman (2001), uma religiosidade "líquida".

Diante desse desafio, o Ensino Religioso pode tornar-se para muitos dos estudantes a primeira consideração profunda, sistemática e oportuna para o desenvolvimento de sua dimensão transcendental. Daí o desafio de escolher um modelo de Ensino Religioso que melhor desenvolva o que a Igreja chama de "pré-evangelização".

Por essa razão, parece que o modelo fenomenológico do Ensino Religioso é o que oferece as melhores condições de dar conta das pluralidades que já se manifestam na maioria das escolas católicas, sem se confundir com a Pastoral Escolar ou com a Catequese, além de ser o mais adequado para acolher as exigências da BNCC. Como demonstrado, essa opção não fere a índole confessional da escola católica, além de prestar um serviço inestimável para a formação integral dos alunos.

Recebido em: 05/03/2019

Revisado pelo autor em: 30/04/2019 Aceito para publicação em: 31/05/2019

\section{Notas}

1 Mestre e doutor em Teologia pela Pontifícia Universidade Católica do Rio de Janeiro (PUC-Rio). Professor de Cultura Religiosa do Departamento de Teologia da PUC-Rio. Gestor administrativo 
da rede educativa da Companhia de Santa Teresa de Jesus. Licenciado em Filosofia. Graduado em Teologia e Informática. Atua também como palestrante do Selo Integra Confessionais da FTD. E-mail: sergiomendes2008@gmail.com

2 A CNBB também se pronunciou de modo semelhante: "O Ensino Religioso na escola é um direito e dever dos alunos e dos pais. E uma dimensão fundamental e necessária de toda a educação, bem como uma exigência da liberdade religiosa de cada pessoa, que tem direito a condições que lhe permitam progredir na sua formação espiritual" (CONFERÊNCIA NACIONAL DOS BISPOS DO BRASIL, 1983, n. 124).

3 São exemplares as seguintes habilidades a serem desenvolvidas no $5^{\circ}$ ano do Ensino Fundamental: "(EF05ER01) Identificar e respeitar acontecimentos sagrados de diferentes culturas e tradições religiosas como recurso para preservar a memória; (EF05ER02) Identificar mitos de criação em diferentes culturas e tradições religiosas; (EF05ER05) Identificar elementos da tradição oral nas culturas e religiosidades indígenas, afro-brasileiras, ciganas, entre outras" (BRASIL, 2017, p. 451).

4 É importante salientar que, na literatura católica sobre o tema, não há consenso quanto às terminologias para classificar os modelos de Ensino Religioso. Por essa razão, apesar das nuances das classificações sobre os modelos de Ensino Religioso em cada autor, optou-se por uma análise mais genérica, porque interessa neste estudo considerar as três principais tendências de orientação dos diversos modelos. Neste tópico, seguiu-se em parte o trabalho de Mateus Geraldo Xavier (2005, p. 19-52).

\section{Referências}

\section{ALBERICH, Emilio. A catequese na Igreja hoje. São Paulo: Ed. Salesiana Dom Bosco, 1983.}

BAUMAN, Zygmunt. Modernidade líquida. Rio de Janeiro: Zahar, 2001.

BRASIL. Base nacional comum curricular. Brasília: MEC, 2017. Disponível em: http://basenacionalcomum.mec.gov.br/images/BNCC_EI_EF_110518_ versaofinal_site.pdf. Acesso em: 5 fev. 2019.

CELAM - Conselho Episcopal Latino-Americano. Documento de Aparecida. Texto conclusivo da V Conferência Geral do Episcopado Latino-americano e do Caribe. Brasília/São Paulo: Edições CNBB, Paulinas, Paulus, 2007.

\section{CONCÍLIO ECUMÊNICO VATICANO II. Constituição Dogmática}

Lumen Gentium: sobre a Igreja. Roma, 21 nov. 1964. Disponível em: http:/ / www.vatican.va/archive/hist_councils/ii_vatican_council/documents/vat-ii_ const_19641121_lumen-gentium_po.html. Acesso em: 5 fev. 2019.

CONCÍLIO ECUMÊNICO VATICANO II. Decreto Ad Gentes: sobre a atividade missionária da Igreja. Roma, 7 dez. 1965. Disponível em: http://www. vatican.va/archive/hist_councils/ii_vatican_council/documents/vat-ii_decree_19651207_ad-gentes_po.html. Acesso em: 5 fev. 2019. 

novada: orientações e conteúdo. Brasília: Editora CNBB, 1983. (Documentos da CNBB, n. 26).

. Para uma pastoral da educação. São Paulo: Paulinas, 1986. (Estudos da CNBB, n. 41).

CONGREGAÇÃO PARA A EDUCAÇÃO CATÓLICA. Dimensão religiosa da educação na escola católica: orientações para a reflexão e a revisão. Roma, 7 abr. 1988. Disponível em: http://www.vatican.va/roman_curia/congregations/ccatheduc/documents/rc_con_ccatheduc_doc_19880407_catholic-school_po.html. Acesso em: 5 fev. 2019.

CONGREGAÇÃO PARA O CLERO. Diretório Geral para a catequese: documentos do magistério. Roma, 15 ago. 1997. Disponível em: http://www. vatican.va/roman_curia/congregations/cclergy/documents/rc_con_ccatheduc_doc_17041998_directory-for-catechesis_po.html. Acesso em: 5 fev. 2019. JOÃO PAULO II. Exortação apostólica Catechesi Tradendae: a catequese no nosso tempo. 4. ed. Petrópolis: Vozes, 1984.

Discurso del Santo Padre Juan Pablo II a un simposio internacional sobre la enseñanza de la religión católica en la escuela (Lunes 15 abril de 1991). Vaticano: Libreria Editrice Vaticana, 1991. Disponível em: https:// w2.vatican.va/content/john-paul-ii/es/speeches/1991/april/documents/hf_jp-ii_spe_19910415_insegnamento-religione.html. Acesso em: 5 fev. 2019.

XAVIER, Mateus Geraldo. Contribuição do ensino religioso no processo de educação da fé: um estudo teológico-pastoral. 2005. Dissertação (Mestrado em Teologia) - PUC-Rio, Rio de Janeiro, 2005. 